\title{
Literature Review on Audit Opinion
}

\author{
Jinyu Tian, Meijin Xin \\ North China Electric Power University, Baoding, China
}

\begin{abstract}
To review the literature could always help us to find the limitation of past studies. This paper offers a literature review concerned with audit opinion from foreign studies to Chinese studies. Audit opinion directly reflects whether the financial statement is true and fair or not, which is the reason why audit is necessary and important. These archives could be divided into two parts, whose elements could influence the quality of audit opinion and how audit opinion impacts on companies and market. The stakeholders value audit opinion and they have different demands of audit opinion to meet their demand. For example, tax department needs the information of revenue and profit to collect tax, creditors need to know the exact number of assets to guarantee their loans, and investors prefer to learn the profitability of companies from financial statements. The article provides a holistic view of audit opinion to give other researchers an implication on which part of audit opinion needs to be studied further.
\end{abstract}

Keywords: audit opinion, literature review, stakeholders

\section{Introduction}

The explanation of audit opinion presented that the Certified Public Accountants (CPA) issue their opinions to the financial statement of the company to certify that the information of financial situation, operation results and cash flow is presented fairly. Audit opinion as a powerful monitor tool could influence the decision of investors and other stakeholders (Bo \& Wu, 2011).

The research studies around the world concerning audit opinion have offered different perspectives to discuss and solutions to problems. However, most of the reviews have only studied one aspect of audit opinion, such as market reactions to unclean opinions (Feldmann \& Read, 2013) and which and how financial index influences audit opinion (Bao \& Chen, 1998; Habib, 2013; Tahinakis \& Samarinas, 2016). Although, delving into the audit opinion in one country or in developed countries could acquire specific information and find own problems, learning other market regulations and experience is the same as exploring own home.

The purpose of the paper is to summarize archives regarding audit opinion from many perspectives, including what exact elements influence audit opinion both internal and external and what is the market response to different audit opinions. Furthermore, this article presents some suggestions for the future studies of audit opinion.

\section{Literature Review}

There is abundant literature on audit opinion from many years ago till now.

Jinyu Tian, Vice Professor, School of Economics and Management, North China Electric Power University.

Meijin Xin, Postgraduate Student, School of Economics and Management, North China Electric Power University. Email: 191830441@qq.com. 
The paper will start with developed countries known as the countries having thorough audit regime. The passage of the Public Company Accounting Reform and Investor Protection Act (Sarbanes-Oxley) in 2002 provoked a heated discussion. The SOX created the Public Company Accounting Oversight Board (PCAOB) to play a role of monitor and regulator of auditing. Moehrle (2016) has argued that warranting the Financial Accounting Standards Board (FASB) independence is so important. Kozloski, Meckfessel, Moehrle, and Williams (2016) have synthesized the literature about the SOX. Shaw and Terando's (2014) results have suggested that the effect of SOX on audit and audit-related fees is strong. Li's (2009) research has explained one of the reasons that the foreign firms left American market, the high cost conforming to SOX, which is related to audit partner rotation. Kwon, Lim, and Simnett (2014) have confirmed that the implementation of SOX did increase audit fees and audit hours in the post-regulation period. Some studies have demonstrated that audit partner rotation always relates to audit opinion shopping (Chow \& Rice, 1982).

The SOX had a belief that audit rotation could assist in improving the presentation of fairer audit reports, while audit firms had the opposite views. Auditors argued, from their experience of executing audit process, that the loss of audit engagement partner continuity would negatively affect audit quality and the quality of financial statement information due to the loss of client familiarity and an increase in information asymmetry. Furthermore, the audit firms argued that these negative effects would be more pronounced during the initial years of a client partner's client engagement (American Institute of Certified Public Accountants [AICPA], 1992). From the empirical research, Litt, Sharma, Simpson, and Tanyi (2014) collected the digit from 2000 to 2004 to show that the association between audit rotation and the quality of audit opinion is negative. The United States General Accounting Office (GAO) has found the same result.

On the opposite, the SOX does improve the quality of audit opinion positively. Lee, Strong, and Zhu (2014) have pointed out that the stricter the regulation is formulated and forced, the fewer mistakes there will be during valuing the price of securities. In Nagy's (2014) report, the demand of the PCAOB to issue audit firm quality control inspection when the firms performed in a poor quality control system decreased market share of the companies. Other departments of government took some actions to perfect their work. Files (2011) has examined that cooperation with the Securities and Exchange Commission (SEC) staff and forthright disclosure of a restatement (e.g., disclosures reported in a timely and visible manner) could reduce the cost of company. Meanwhile, the cooperation works in a more efficient and effective way to present fair financial statement and reduce the risk of audit opinion. Besides the enforcement, the setters also pay attention to explaining concept in detail. PCAOB issued AS 3101.20 in 2015 explaining that a qualified opinion assures that the financial statements are fairly presented in all material aspects, with only one part having quality problems. An adverse opinion and a disclaimer of opinion, just the opposite, cannot offer guarantee concerning the financial statements to the investors and other relative beneficiaries (Cipriano, Hamilton, \& Vandervelde, 2016).

From the perspective of auditors, sometimes they would change their opinion. Some researchers have involved in auditors modifying their opinions. The behavior could generate clean opinion whether it is standard unqualified opinions or not at start. The opinions excluded from the most common standard unqualified opinions including qualified reports, adverse reports, disclaimer of opinion reports as well as unqualified reports with explanatory paragraphs. One study using standard meta-analysis regarding 73 published empirical studies has showed situations under which auditors have motives to modify their opinions. Modified audit opinion is significantly influenced by Big $\mathrm{N}$ audit affiliation, audit report lag, and non-audit fees variables of the perspective of auditor and audit-related characteristics. Furthermore, firm-specific variables, in detail, size 
of firms, profitability, debt structure and prior GC opinion have much more impacts than the former variables on modified audit opinion (Habib, 2013).

Audit opinion is significantly important to capital market and shareholders. Tahinakis and Samarinas (2016) have employed a value relevance model to explore the reaction of the markets and investors to the audit opinions. They sought evidences of the view that investors trust unqualified audit opinions even if there are some skeptical arguments to the auditing process. In addition, qualified audit opinion negatively affects the investing public. The study also shows that the auditors should take the responsibility to be professional to verify the financial statements. Furthermore, debt market also has responses to audit opinion. Feldmann and Read (2013) collecting information from BankruptcyData.com have covered the gap that the audit opinions of going-concern have a close relation with credit rating issued by Standard \& Poor's (S\&P). They released that after receiving going-concern reports, the distressed companies are probably downgraded immediately followed by auditors accomplishing their jobs. To be more precise, only one company at the bankrupt level did not conform to the finding. Besides, the firms on the down list of credit rating one month before the audit date have a higher likelihood to get going-concern reports.

Audit opinion also influences other aspects. Buchman and Collins (1998) have showed that the qualified audit opinions have a higher likelihood to cost the firms in lawsuit compared with the unqualified opinions.

After delving into abundance studies, some researchers have come up with some solutions to improve the quality of audit opinion. To start with the PCAOB, it is important to know which could change its responses to qualified audit opinion. Now that the rate of restatements by each year is higher than the prior of qualified opinions, it could be better to permit the auditors to issue qualified audit opinions instead of imposing restrictions on the audit report concerned about qualified audit opinions of listing companies (Cipriano et al., 2016). Simnett and Huggins (2014) concluded that the current reporting model is deficient and could be improved for the stakeholders have less interests and motives to utilize the report. Confronted with the challenge, Financial Reporting Council (UK), the International Auditing and Assurance Standards Board (IAASB), the European Commission, and the PCAOB (USA) considered taking some measures to change audit report to suit the market and stakeholders. The setters took some initiatives including providing enhanced information about the responsibilities of those involved in the financial reporting process, asking the disclosing of the name of the engagement partners in charge of the audit, and improved disclosure about the auditor's judgments and processes.

Actually, China did better than these developed countries involving in the disclosure about the name of audit partners. Chinese regulators have designed that the audit reports need two CPAs to sign their name to ensure that the issuance is fair enough to stakeholders (Cai, Yang, X. Chen, \& Y. Chen, 2005).

In China, some research studies about audit opinions have been conducted. The regime of Chinese market is not sound, and regulators and auditors should pay more attention to the exploration of the influence of audit opinion on the market and companies.

Chinese researchers have also explored the elements influencing audit opinion. Firstly, the audit clients, namely public companies, would influence audit opinion. Tian (2007) has employed an empirical analysis using Chi-Square test with the figures from A-shared companies through 2005-2006 to argue that companies whose financial statements are in a good state are less likely to acquire qualified audit opinions. Furthermore, it takes more time for qualified audit opinions to be issued compared to unqualified audit opinions. The researcher has also set forth the positive relationship between small profit and qualified audit opinions. In addition, Bao and Chen (1998) have demonstrated that asset-liability ratio, profit and loss, return on assets 
(ROA), and the region of the company registered have a strong influence on audit opinion. When the above elements present negative, auditors have a higher likelihood to issue non-standard unqualified audit opinion. The geographic difference of Shenzhen City, having more propensities to issue negative audit opinion compared to other cities in China, is evident. Bo and Wu (2011) have argued that the higher the information risk, the more intentions to issue unclean audit opinion.

Audit opinion shopping is the action taken by companies, but companies always exert pressure on auditors to change opinion fundamentally. Some foreign researchers have studied that auditors often modified their opinions because of audit opinion shopping. Researchers in China explored the problem occurring in Chinese market. The existence of opinion shopping as an effective way to acquire unqualified opinions to financial statement shows that the firms could impact the audit opinion significantly. Chen, Peng, Xue, Yang, and Ye (2016) have noticed that studies involved in companies shopping opinions lay out that the corporations could always purchase what they need by switching audit firms. Thus, they moved forward to examine whether companies successfully engage in partner-level opinion shopping in China. The evidences collected from 11,919 observations from 1998 to 2012 confirm that companies using the way of switch partners always achieve clean opinions. The result consists with the findings of Habib (2013) who researched published archives in the scope of whole world.

Secondly, the environment has strongly influenced audit opinion. Yu, Zhang, and Liang (2013) have pointed out that the oversight of media could obviously improve the quality of audit opinion and raise more cautions of auditors through the sample collected from A-shared market in China during the period of 2001-2009. They demonstrated that the more negative news regarding companies, the more propensity of auditor to issue non-standard unqualified audit opinion. Furthermore, the scholars have found that the audit opinion presented subsequent year would have improved because of the negative news last year. The two elements have positive coefficient, the more bad information, the more possibility to ameliorate the quality of audit opinion. At the meantime, the reputation of Big $\mathrm{N}$ audit affiliation has less association with the above result. They set forth that multimedia play an important role in improving market environment and to some extent solving the problem of asymmetric information between auditors and listed firms. Given the political elements, X. Du, Zhou, and Y. Du (2011) have demonstrated that political relation has a strong influence on the choice to auditors of state-owned enterprises. Precisely, the companies prefer small audit firms in their region to acquire clean opinion when they are close to government.

The reaction of market to audit opinion has been considered by Chinese researchers. Wei, Wang, Wu, and Li (2012) have used the figures of 1,555 listed firms in Shanghai stock market from 2006 to 2009 and concluded that audit opinion does influence the cost of liabilities and the role of supervision by auditors could improve the environment of capital market together with increasing the efficiency of resources deployment. Furthermore, they set forth that non-standard unqualified audit opinions were probably received by companies which have a higher cost to acquire debt.

\section{Conclusion}

Audit opinion is a contentious center of audit and accounting, which could attract public firms, audit firms and regulators together with others. The paper summaries literatures from foreign archives to Chinese studies regarding audit opinion. Chinese studies could follow with the international step and also focus on Chinese own features. 
Audit opinion verifies the financial statement of companies published fairly. Stakeholders pay close attention to audit opinion. Different stakeholders have different expectations from audit opinion (Litt et al., 2014). Public companies, which collect capital from public, have to employ professional auditors to audit financial statements and get their audit opinion, which could warrant the figures in the statement are fair. Public companies have the motives to achieve clean audit opinion even if they cannot present fair financial statement to the market. Since audit opinion verifies the information companies published authenticity, shareholders could make their decision relying on financial statement. As for auditors, they must abide by the accounting standard and other related regulations. In addition, they should exert effort on improving professional quality and skills. The policymakers take the burden of ensuring fairness and justice of market operation. They have willingness to find the problems in the auditing process and ensure fair audit opinion. Thus, they could make full use of the studies to improve the quality of audit opinion by reforming the audit regime.

The limitation of the article is that the content is not enough to explain the state of studies in audit opinion.

Future study should focus on the field that how to issue more fair audit opinion to obtain reasonable assurance about whether the financial statements are free of material misstatements, whether caused by error or fraud.

\section{References}

American Institute of Certified Public Accountants [AICPA]. (1992). Statement of position regarding mandatory rotation of audit firms of publicly held companies. New York, NY: AICPA.

Bao, B., \& Chen, G. (1998). Audit qualifications prediction using accounting and market variables: The case of Chinese listed companies. Working Paper.

Bo, X., \& Wu, L. (2011). Earnings management information risk and audit opinion. Audit Research, 1, 90-97.

Buchman, T. A., \& Collins, D. (1998). Uncertainty about litigation losses and auditors' modified audit reports. Journal of Business Research, 43(2), 57-63.

Cai, C., Yang, L., Chen, X., \& Chen, Y. (2005). The empirical analysis of the factors leading to the audit opinions. Finance and Economics, 1, 95-102.

Chen, F., Peng, S., Xue, S., Yang, Z., \& Ye, F. (2016). Do audit clients successfully engage in opinion shopping? Partner-level evidence. Journal of Accounting Research, 54(1), 79-112.

Chow, C. W., \& Rice, S. J. (1982). Qualified audit opinions and auditor switching. The Accounting Review, 57(2), 326-335.

Cipriano, M., Hamilton, E. L., \& Vandervelde, S. D. (2016). Has the lack of use of the qualified audit opinion turned it into the "Rotten Kid” threat? Critical Perspectives on Accounting. Retrieved from http://dx.doi.org/10.1016/j.cpa.2016.10.001

Du, X., Zhou, Z., \& Du, Y. (2011). Political connections, regional preference of audit choice and audit opinions-Evidence from Chinese state-owned listed companies. Audit Research, 2, 77-86.

Feldmann, D., \& Read, W. J. (2013). Going-concern audit opinions for bankrupt companies - Impact of credit rating. Managerial Auditing Journal, 28(4), 345-363.

Files, R. (2012). SEC enforcement: Does forthright disclosure and cooperation really matter? Journal of Accounting and Economics, 53(1-2), 353-374.

Habib, A. (2013). A meta-analysis of the determinants of modified audit opinion decisions. Managerial Auditing Journal, 28(3), 184-216.

Kozloski, T., Meckfessel, M., Moehrle, S. R., \& Williams, T. (2016). Developments in accounting regulation: A synthesis and annotated bibliography of evidence and commentary in the 2014 academic literature. Research in Accounting Regulation, 28(1), 22-41.

Kwon, S. Y., Lim, Y., \& Simnett, R. (2014). The effect of mandatory audit firm rotation on audit quality and audit fees: Empirical evidence from the Korean audit market. Auditing: A Journal of Practice \& Theory, 33(4), 167-196.

Lee, E., Strong, N., \& Zhu, Z. (2014). Did regulation fair disclosure, SOX and other analyst regulations reduce security mispricing? Journal of Accounting Research, 52(3), 733-774.

Li, C. (2009). Does client importance affect auditor independence at the office level? Empirical evidence from going-concern opinions. Contemporary Accounting Research, 26(1), 201-230. 
Litt, B., Sharma, D. S., Simpson, T., \& Tanyi, P. N. (2014). Audit partner rotation and financial reporting quality. Auditing: A Journal of Practice \& Theory, 33(3), 59-86.

Moehrle, S. R. (2016). Book view of the FASB: The people, the process, and the politics, 5th Edition. Research in Accounting Regulation, 28(1), 60-62.

Nagy, A. (2014). PCAOB quality control inspection reports and auditor reputation. Auditing: A Journal of Practice \& Theory, 33(3), 87-104.

Shaw, W. H., \& Terando, W. D. (2014). The cost of compliance to Sarbanes-Oxley: An examination of the real estate investment industry. Auditing: A Journal of Practice \& Theory, 33(1), 177-186.

Simnett, R., \& Huggins, A. (2014). Enhancing the auditor's report: To what extent is there support for the IAASB's proposed changes? Accounting Horizons, 28(4), 719-747.

Tahinakis, P., \& Samarinas, M. (2016). The incremental information content of audit opinion. Journal of Applied Accounting Research, 17(2), 139-169.

Tian, L. (2007). The empirical analysis of the determinants of the audit opinion. Journal of Zhongnan University of Economics and Law, 6, 116-122.

Wei, Z., Wang, Z., Wu, Y., \& Li, C. (2012). The environment of capital market, audit opinion and the cost of liability. Audit Research, 3, 98-105.

Yu, Y., Zhang, J., \& Liang, H. (2013). Does media monitoring affect audit opinion? Empirical evidence from China securities market. Audit Theory Research, 1, 26-36. 